\title{
Direct and indirect utilitarianism in Bentham's theory of adjudication
}

\author{
FRANCESO FERRARO \\ Dipartimento di Scienze Giuridiche 'Cesare Beccaria', Università degli Studi di \\ Milano \\ francesco.ferraro@unimi.it
}

\section{Introduction}

There is still some disagreement about the nature of Jeremy Bentham's utilitarianism as applied to his theory of law and adjudication. Most commentators have ascribed to him an indirect-utilitarian prescriptive theory with regard to adjudication. Bentham sought to replace the common law system with a wholly codified body of law, issued by a utilitarian legislator. The role of the judges under such a system would be that of adjudicating by strictly applying the laws in the code. This leads to an indirectutilitarian theory in that the judges would not decide at case-level by applying directly the principle of utility, but they would rather apply general rules which, in turn, were enacted on utilitarian grounds. Utilitarian maximization, then, would be pursued only indirectly by the judges.

In his Bentham and the Common Law Tradition, Gerald Postema has put forward a different account that credits the philosopher with a direct-utilitarian theory of judicial decision. ${ }^{1}$ According to him, Benthamic judges are required to appeal directly to the principle of utility when deciding a case. Compliance with the legislator's will, expressed in the law, should be laid aside whenever utilitarian considerations require so. Postema's 'revisionist' interpretation - which also involved a rethinking of Bentham's avowed project of codification of law in a 'complete code' or Pannomion - has been criticized by John Dinwiddy, who has ascribed to Bentham a completely different position. According to Dinwiddy, Postema has confused Bentham's views on legal procedure or 'adjective law' with those on substantive law. ${ }^{2}$ While the judges should be freed from unreasonable constraints in the field of procedure, they should never be allowed to dispense with substantive law, not even on

\footnotetext{
${ }^{1}$ G. J. Postema, Bentham and the Common Law Tradition, Oxford, 1986.

2 J. Dinwiddy, 'Adjudication Under Bentham's Pannomion' in Bentham: Selected Writings by John Dinwiddy, ed. W. Twining, Stanford, 2004, pp. 155-157.
} 
utilitarian considerations. They should rather be allowed - required, indeed - to halt their decision and propose emendation of the law to the legislator, whenever they think that applying the law as it is would lead to undesirable and anti-utilitarian results.

It is worth remarking that the opposition between direct and indirect utilitarianism, which is here being made reference to, is an opposition between two different strategies of decision. In reaching for a decision, a direct-utilitarian judge will appeal directly to utilitarian evaluation and calculation, trying to maximize overall utility with his legal sentence. On the contrary, an indirect-utilitarian judge will lay aside utilitarian calculations, to decide the case according to general rules which are supposed to obtain best results in utilitarian terms. In a context of statute law, like the one which Bentham devised, this means applying the laws issued by a utilitarian legislator.

\section{Postema vs. Dinwiddy on the role of the judge under Bentham's Pannomion}

Gerald Postema has interpreted the role of Bentham's judge as that of a utilitarian who decides according to what, in his/her view, seems to maximize overall utility. Even under a system of codified law, like Bentham's Pannomion, judges should be left free to adjudicate appealing to direct-utilitarian calculation. According to Postema's interpretation, the laws contained in the 'complete code' should not be binding on judges, at least when they seemingly dictate legal consequences which contradict utilitarian calculations. These laws would be no more than broad general principles and/or advice from the legislator to the judges. Most of all, they would provide the judge with a 'list of the relevant expectations' which are at stake in each case. Respect of law-induced expectations is of paramount importance in Bentham's legal utilitarianism: he envisaged a Disappointment-preventive or Non-disappointment principle, which 'in the genealogy of human feelings' was to be considered as 'the immediate lineal descendant of that same parent principle', that is the principle of utility. ${ }^{3}$ Pain of disappointment was very weighty in the final balance of utility and it had to be minimized as far as possible. It damaged the security of the members of the political community, which, along with subsistence, abundance, and equality was one of the four 'subordinate ends' or 'subordinate objects' of the principle of utility -

\footnotetext{
3 'Equity Dispatch Court Proposal', in The Works of Jeremy Bentham, ed. J. Bowring, 11 vols., Edinburgh, 1843, iii. p. 312 [hereafter 'Bowring'].
} 
probably the most important of the four. ${ }^{4}$ In Postema's view, however, Bentham sought to protect security of expectations without sacrificing the flexibility of the legal system at case-level. Both had to be provided for by judges, who were to be released from strict constraints by the legislator and left free to pursue utilitarian maximization.

Postema's interpretation has been challenged by John Dinwiddy, who offers a different account of the solution devised by Bentham to the problem of accommodating security of expectations and the necessary flexibility of the legal system. ${ }^{5}$ Dinwiddy quotes passages from Bentham's Constitutional Code, where, in his opinion, Bentham's fullest and most mature discussion of the role of the judges in a utilitarian legal system can be found. In the Constitutional Code Bentham makes it clear that judges should never deliver decisions that contravene laws issued by the legislator. The Constitutional Code contains a 'Judges' Inaugural Declaration', in which judges commit themselves never to substitute their will to the will of the Legislature, even in those cases in which the law is, in their view, 'inexpedient'. The only exception to this rule admitted of by the Declaration is 'the exercise of such discretionary suspensive power' which the legislator has explicitly conferred to the judges. ${ }^{6}$ This discretionary suspensive power is condensed by Bentham in two functions, which the judges should be assigned: the sistitive and the eventuallyemendative function. The former amounts to the power to suspend the final judgment on account of an imperfection of the law, which would lead to undesirable results if applied. The latter is the faculty of proposing amendments to the law, once the sistitive function has allowed the judge to suspend his/her decision. By exercising these functions, then, judges can avoid application of the law in all those cases where it would, in their opinion, obtain anti-utilitarian outcomes. Once their proposal for emendation has been issued, the legislature has to express its final will, accepting or rejecting it. This, then, as Dinwiddy points out, is how Bentham thought that the legal system could receive its necessary flexibility without damaging security of expectations. In this way the complete code of laws, or Pannomion, would continuously be open to improvement and could be adapted to perpetually-changing

\footnotetext{
4 'Principles of the Civil Code' in Bowring, i. p. 312 and 'Constitutional Code' in Bowring, ix. p. 11. See also P.J. Kelly, Utilitarianism and Distributive Justice: Jeremy Bentham and the Civil Law, Oxford, 1990, pp. 71-103.

${ }^{5}$ See Dinwiddy, 'Adjudication', pp. 155-162.

6 'Constitutional Code' in Bowring, ix. p. 533. See also Dinwiddy, 'Adjudication', p. 160.
} 
circumstances, without losing its character of a systematically-arranged, tidy, and easily understandable body of laws. The legal system would be preserved as a unitary and organic structure with its centre in the code; no need for strained interpretations would arise, thus avoiding the rebirth of judge-made common law. ${ }^{7}$

According to Dinwiddy, then, the Benthamic utilitarian judge should not ground his/her decisions on direct calculations of utility, but only on an application of the rules issued by the legislator. Whenever it is likely that anti-utilitarian consequences would ensue, the judge should stay execution of the law as it is and wait for the legislator to accept or refuse an amendment of his/her proposal. In no case can judges set aside the law to decide by direct application of the principle of utility and according to their own utilitarian calculations, as suggested by Postema. The sistitive and the eventually-emendative functions provide all the flexibility the system needs. As a matter of fact, Postema acknowledges Bentham's account of these functions in the Constitutional Code, but he denies that they should be taken as the only possibility for the judges to contribute to the utilitarian flexibility of the system. He suggests that proposed alteration of the law is not requisite for questioning its strict application; in his view, Bentham leaves the judges free to choose between dispensing with the law to apply their utilitarian calculations and staying its execution to propose an amendment. ${ }^{8}$ This interpretation, anyway, looks difficult to hold, mainly due to lack of textual evidence. Moreover, it clashes with a passage of the Constitutional Code which states that, whenever the judge disapproves on utilitarian grounds of the expected outcome of the law in a certain case, 'it is not only allowable to him, but on his responsibility, rendered incumbent on him, to stay execution accordingly'. 9 As with all other terms employed by Bentham, 'responsibility' is given by him a very precise meaning: it means subjection to punishment. No responsibility has place without the threat of an eventual punishment. ${ }^{10}$ Also 'obligation' - which is considered by Bentham as the 'name of a fictitious entity' - is analyzed by him in terms of subjection to a probable punishment, together with its synonym 'duty'. ${ }^{11}$ The passage above, then, means that judges should be put under an obligation or a duty to exercise the two aforementioned functions whenever it seems expedient, and that they

\footnotetext{
7 'Constitutional Code' in Bowring, ix, p. 512. See also Dinwiddy, 'Adjudication', p. 161.

${ }^{8}$ Postema, Bentham and the Common Law, pp. 434-439.

9 'Constitutional Code' in Bowring, ix. p. 508; see also Dinwiddy, 'Adjudication', pp. 159-160.

${ }^{10}$ See Constitutional Code, Volume I, eds. F. Rosen and J. H. Burns, Oxford, 1983 (The Collected Works of Jeremy Bentham, hereafter $C W$ ), pp. 21-22n.

${ }^{11}$ See, for example, 'Essay on Logic' in Bowring, viii. p. 247.
} 
should be punished if, in case they think that the case in question cannot be decided properly by applying the law, they refrain from suggesting an emendation of the code to the legislature.

Dinwiddy's interpretation, then, looks more faithful to Bentham's views. In support of this view, textual evidence from writings on Scotch Reform can be added to that contained in the Constitutional Code. The former were occasioned by Parliamentary debate on changes in Scottish civil procedure ${ }^{12}$. Bentham sketched in them the characteristics of his ideal 'natural system of procedure', as opposed to the 'technical system' of English common law procedure. ${ }^{13} \mathrm{He}$ was clear that the judges should be left free from procedural constraints; but, as regards compliance with substantive law, they should maximize application of the legislator's will. How should the judge treat, then, those cases in which legislative will contrasts with the dictates of utility?

In this case to which of the two standards shall his decision be conformable? [...] The will of the sovereign? Oh then he is a vile and prostitute slave, a tool at the command of every tyrant that will deign to make use of him. The welfare of the people? Oh then he is an insurrectionist, an anarchist: or rather under the mask of democracy: a despot. Difficult and slippery as the question is - it is much better to face it openly and calmly than to avoid it altogether, or to answer it by a response purposely ambiguous or obscure. ${ }^{14}$

While recognizing the problem raised by this conflict, Bentham is very clear on the desirable solution:

By the Judge then what is it that ought to be taken for the standard of rectitude, of decision? The will of the sovereign, or the welfare of the people? The answer plainly, is - the will of the sovereign as far as it is known: otherwise he himself is sovereign as well as Judge. Shall it be the welfare of the people? Shall his decision be that which in his own

\footnotetext{
12 A.J. Draper, 'Corruptions in the Administration of Justice: Bentham's Critique of Civil Procedure, 1806-1811', Journal of Bentham Studies, vol 7 (2004).

13 'Letters on Scotch Reform' in Bowring, v. p. 7.

${ }^{14}$ UC cvi 195.
} 
opinion, real or pretended, is most conducive to the welfare of the people, no regard being at the same time paid to the will of the sovereign, or of any other person than himself? Acting thus is acting exactly as the sovereign himself does: this is not judicature, but sovereignty. ${ }^{15}$

There is a 'middle course' for the judge between applying a law that would lead to anti-utilitarian results and dispensing with it to decide according to his/her own calculations of utility.

In all ordinary cases [...] between decision in precise conformity to the will of the sovereign, and decision in non-conformity and opposition to it, there is a middle course: and a course which under every government might be permitted and pursued with perfect safety. This is - to authorize the Judge when he sees occasion, after declaring that decision which to him appears to be conformable to, and called for by the declared will of the sovereign, taken as it stands at present, to suspend the execution (taking the requisite measures for the prevention of irreparable damage) till after the particular case shall have been represented to the sovereign, and his particular will signified in consequence. $^{16}$

Judicial decision, then, should always be based on the law, which expresses the will of the legislator. In this respect the judge should be an indirect-utilitarian, not acting according to a direct application of the principle of utility, but in compliance with rules issued by the legislator - rules which are supposed to maximize utility. Whenever these rules seem not to obtain best results, the function of the judge is to suggest that they be modified; in case the legislature should accept the proposed modifications, courts will have to apply the amended rule.

This account, by the way, only covers a part of the field of the judges' tasks. In Scotch Reform Bentham also explains that 'adjective law', that is the law of judicial procedure, should have two different kinds of ends, which he calls the 'ends of

\footnotetext{
${ }^{15}$ UC cvi 194.

${ }^{16}$ UC cvi 197.
} 
justice'. The ends of justice can be 'direct' and 'collateral'. The former are 'prevention of misdecision [...] and failure of justice ${ }^{17}$ : they regard the execution of the laws of the 'substantive branch', which express the legislator's will. The latter ends, instead, are 'prevention of delay, vexation, and expense, in so far as superfluous, or preponderant (viz. over the mischief from misdecision or from failure of justice) ${ }^{18}$. The direct ends of justice can be seen as establishing an indirect relation of procedural law with the principle of utility, in the sense that they aim to maximize application of substantive (utilitarian) law, not to maximize utility. On the contrary, the collateral ends of justice must be pursued by judges in a direct-utilitarian fashion, because they ascribe to them the responsibility to calculate relevant utilities and minimize disutilities for the parties, the witnesses and all other people involved in the trial. In the 'natural system of procedure' the judge is left free to pursue the ends of justice, both direct and collateral, without procedural constraints.

The field of evidence is where Bentham most clearly ascribes to judges both freedom from procedural rules and responsibility for making utilitarian calculations. His rejection of strict laws of evidence has led William Twining to call him an antinomian in this respect. ${ }^{19}$ Bentham is mostly concerned with those 'exclusionary rules' that ruled out classes of evidence like hearsay and self-inculpating. The Benthamic judge should be left completely free to take into account any evidence he/she pleases. The only limitations to this liberty should come from utilitarian considerations relating to the collateral ends of justice, namely to the purpose of minimizing unnecessary inconveniences for all concerned: 'the rule will be,--Let in the light of evidence. The exception will be,-Except where the letting in of such light is attended with preponderant collateral inconvenience, in the shape of vexation, expense, and delay' ${ }^{20}$. Cases may arise in which the benefit expected for the 'direct ends of justice' is clearly overbalanced by the collateral damages that examination of a certain piece of evidence would provoke.

By laying a barrow-full of rubbish on a spot on which it ought not to have been laid (the side of a turnpike road,) Titius has incurred a penalty

\footnotetext{
17 'Scotch Reform' in Bowring, v. p. 5

${ }^{18}$ Ibid., p. 5

${ }^{19}$ W. Twining, Theories of Evidence: Bentham and Wigmore, London, 1985, pp. $66 \mathrm{ff}$; and W.

Twining, 'Bentham on Evidence' in Jeremy Bentham: Moral, Political and Legal Philosophy, ed. G.J. Postema, 2 vols, Aldershot, 2002, ii. pp. 443 ff.

20 'Rationale of Judicial Evidence [RJE], Part II' in Bowring, vii. p. 336.
} 
of five shillings. No man was witness to the transaction but Sempronius; and, in the station of writer, Sempronius is gone to make his fortune in the East Indies. Should Sempronius be forced, if he could be forced, to come back from the East Indies for the chance of subjecting Titius to this penalty? Who would think of subjecting Sempronius to the vexation?-who would think of subjecting Sempronius, or anybody else, to the expense? ${ }^{21}$

This can be taken as an example of a conflict between the direct and the collateral ends of justice. Bentham recognizes that such a conflict is frequent and unavoidable:

Throughout the whole field of Judicial Procedure, conflict [...] has place between the direct ends of justice [...] and the collateral $[\ldots]$ and on which side shall be the claim to preference, will, in each individual instance, depend upon the circumstances of the individual case. ${ }^{22}$

The end of maximizing execution of the substantive laws is not to be taken as always prevailing over that of minimizing delay, vexation and expense:

The quantity of vexation, expense, and delay, without which the course necessary to the execution of the article of substantive law in question cannot be pursued with effect,- - the price thus necessary to be paid for the chance of obtaining the benefit in question,- - does it exceed the value of that benefit, or rather of that chance? In such case the price ought not to be paid: the law ought rather to remain unexecuted. ${ }^{23}$

The last two passages quoted above have been taken by Postema as proof of the fact that, in Bentham's view, the absence of strict rules is not to be confined to procedural matters, but it is part of his model of how substantive laws should be

\footnotetext{
${ }^{21}$ Ibid.

22 'Constitutional Code' in Bowring, ix. p. 463

23 'RJE ii' in Bowring, vii. p. 335
} 
applied in courts. ${ }^{24}$ According to Postema, Bentham leaves judges the responsibility to dispense with the law enacted by the legislature, whenever their direct-utilitarian calculations seem to advice so.

Surely Postema has a point in claiming that some of the tasks of the Benthamic judge involve direct application of the principle of utility. Nonetheless, Bentham does not say that substantive laws should be dispensed with when they seem to attain suboptimal results, nor that judicial calculations of utility should be substituted to the application of the laws. He rather appeals to the common sense of the judges as regards examination of evidence. Wherever such examination would entail collateral damages superior to the expected benefit of applying the law, the judges should give in and do without the piece of evidence in question. There is little doubt this involves autonomous utilitarian calculation on the part of the judges; but this amounts by no means to setting aside the law and substituting direct application of the principle of utility to applying the will of the legislator. The judges are required to take into account the costs and benefits of examining any piece of evidence. Should they choose not to admit it on account of excessive costs - in terms of delay, vexation, and expense - they consciously run the risk not to be able to form a correct judgment. There is a chance, as Bentham says, that the excluded piece of evidence would have contributed to the direct ends of justice, that is, avoiding misdecision and failure of justice. This chance must be included into a balance that, on the other side, also takes into account probable drawbacks in terms of delay, vexation, and expense, mostly for parties and witnesses. These are complex direct-utilitarian calculations that are required of the judges, but they do not involve the possibility of discarding laws enacted by the legislature on account of their anti-utilitarian consequences. This is rather a solution to a conflict between the two different ends of adjective law. In Postema's interpretation Benthamic judges seem to be trusted with the power to act on the level of substantial law by substituting their own will to that of the legislator. Bentham's position, instead, seems rather to be that the judges should be left free to appeal to direct-utilitarian calculations in order to settle a conflict between the two ends of adjective law. The legislature itself should require them to do so. ${ }^{25}$ Conflicts of this kind belong to judicial procedure and they can be seen as affecting the relations between this and substantive law. They are quite different from those

\footnotetext{
${ }^{24}$ Postema, Common Law Tradition, pp. 345-347.

25 'RJE ii' in Bowring, vii. pp. 344-345.
} 
conflicts issuing from cases in which application of a law on the one side, and direct judicial application of the principle of utility on the other, would result in two different judicial decisions. This latter kind of conflict wholly belongs to the field of substantive law, at least in Bentham's view.

Moreover, freedom for the judges not to take into account any evidence, the examination of which would tilt the balance of utility on the wrong side, does not mean complete freedom from constraints from the legislator, nor disregard for the application of substantive law.

Direct utilitarian calculation on the part of the judges must take into account the risk of the non-application of laws. In deciding whether to refuse a piece of evidence in order to avoid excessive delay, vexation, and expense, the judge has to take into account both the 'amount of mischief' produced by misdecision or by failure of justice in the particular case and the danger of misdecision or failure of justice. The former 'depends upon the nature and importance of the cause'. In criminal cases, both the seriousness of the offence and the quantity of the punishment must be taken into account. In non-criminal cases the expected benefit and mischief at stake for the parties are to be weighed. ${ }^{26}$ As for the latter, that is the danger of misdecision or failure of justice, this is clearly a case of probability to be assessed by the judge, who has to evaluate how much excluding the evidence in question would increase the risk of a wrong decision. ${ }^{27}$ Now, we can reasonably ascribe to Bentham the view that in many cases - mainly criminal ones - the sheer quantity of the damage, which a wrong decision would provoke, would be enough to prompt the judge to admit any available evidence, without much regard for collateral damages like delay, vexation, and expense, which would be outweighed in the final balance of utility.

The reason why Bentham leaves room for such direct-utilitarian calculations on the part of the judges is that this is a necessary part of the global utilitarian strategy of the legislator. In his view, it is impossible to lay down general rules for deciding in each case whether to admit or not a certain piece of evidence. Due to the infinite variety of circumstances, which influence the final outcome of the utilitarian calculation, this is something that should be left for the judge to assess. This is the reason why the legislative authority ought 'to leave, or rather to place, in the hands of

\footnotetext{
${ }^{26}$ Also taking into account those 'circumstances influencing sensibility' which Bentham lists in Ch. VI of An Introduction to the Principles of Morals and Legislation, ed. J. H. Burns and H. L. A. Hart, Oxford, 1996 (The Collected Works of Jeremy Bentham), p. 49 [hereafted IPML $(C W)$ ].

27 'RJE ii' in Bowring, vii. p.344.
} 
the judicial, such a latitude of discretionary power, as shall enable it to form an estimate' of the mischief resulting from exclusion of evidence and of that expected from its admission. The judges will have to draw the balance in each individual instance, on the occasion of each individual suit'. ${ }^{28}$ This 'discretionary power' is conferred to them by the utilitarian legislator, who acknowledges that general mandatory rules cannot obtain the maximization of utility as regards admission of evidence. Once again, this is no power to substitute the judge's will to the legislator's will expressed by substantive laws. It is rather part of an anti-nomian conception of judicial procedure.

\section{The Equity Dispatch Court: a model of Benthamic adjudication?}

Much of Postema's interpretation draws on Bentham's writings proposing the establishment of an 'Equity Dispatch Court'. This court was meant to supplant all existing English courts of equity and especially the Court of Chancery. Courts like the Chancery, born in the Middle Ages to adjudicate free from the procedural constraints of the common law, had lost their original character and had adopted binding procedures and the principle of stare decisis. During the $18^{\text {th }}$ century, equity procedures had become even stricter than common law ones and had reached an unbearable level of inefficiency and slowness. In 1829 Bentham published his Equity Dispatch Court Proposal and started a subscription in its support. The failure of this subscription did not prevent him from publishing also a complete Equity Dispatch Court Bill in $1831^{29}$. In the Equity Dispatch Court writings the author displays the same anti-nomian views on procedural law that he entertained at the time he wrote on Scotch Reform. Moreover, freedom of the judges from fixed procedures receives here even more emphasis. The single-seated judge of the new proposed court would be entitled to the exercise of considerable powers upon the suitors and all those involved in the cause. These powers included that of issuing particular orders for the dispatch of the suit, together with the power to punish non-compliance (punitive power) and even that of encouraging compliance with rewards (remunerative power). Not only would the Equity Dispatch Court judge be entitled to issue particular commands, but he/she would also be conferred the power to establish general rules to be observed by

\footnotetext{
${ }^{28}$ Ibid., pp. 344-345.

${ }^{29}$ W. Holdsworth, A History of English Law, 17 vols, London, 1952, xiii. pp. 99-100.
} 
all those involved in the suit, during its whole duration (self-regulative power $)^{30}$. Moreover, the judge should be given a self-extensive power, that is a power 'exercisable in so far as by experience, or [...] anticipation, the several other powers hereby instituted and conferred may have come to be, in the eyes of the Dispatch Court Judge, insufficient ${ }^{31}$. This is in effect the power to produce changes in substantive law, by issuing 'Judiciary-bred Acts', subject to a 7-day period of evaluation by Parliament and the Monarch. When this period expires without express disallowance or suspension, the new Act acquires the same validity as any Act of Parliament. This latter power - which Bentham himself recognizes as 'unprecedented" ${ }^{32}$ - is meant to achieve the following results:

Making, without the delay of an Act of Parliament and the correspondent consumption of the time of Parliament, provision for unforeseen defects and exigencies. ii. Committing to the functionary who, by his appropriate aptitude, derived from such experience and correspondent attention as cannot have had place in the instance of any other person, is best qualified, the duty of making on each occasion the provision requisite. iii. Giving an example of an arrangement, having for one of its objects, or say ends in view, the maintenance of the constitutional subordination of the judicial authority to that of the legislature. iv. In outside show, by this arrangement, addition is made to the power of the Judge; in design it is, and in effect it will be seen to be- - the applying a limitation to it: and that a highly needful one. ${ }^{33}$

In Bentham's view, as long as judicial subjection to the legislative authority is guaranteed, there is no judge-made law. 'Judiciary-bred' acts and amendments acquire the force of law whenever they follow fixed proceedings, which allow the legislator to repeal or to adopt them (explicitly or tacitly).

Postema's overall interpretation of the Benthamic system of adjudication as a direct-utilitarian one finds some support in a passage of the Equity Dispatch Court Bill where Bentham declares that 'so far as regards the matter of law, every decision

\footnotetext{
30 'Equity Dispatch Court Bill' in Bowring, iii. p. 347.

${ }^{31}$ Ibid., p. 347.

${ }^{32}$ Ibid., p. 369.

${ }^{33}$ Ibid., p. 369.
} 
of the Dispatch Court Judge will have for its ground the non-disappointment principle, ${ }^{34}$ This is also called the disappointment-preventive principle and is considered by him as 'the immediate lineal descendant' of the principle of utility 'in the genealogy of human feelings ${ }^{35}$. This principle prescribes minimization of all possible disappointment of the citizens' expectations and its importance is paramount in all legal matters concerning property. Postema correctly considers it as a 'deputy' of the principle of utility and points out that the Dispatch Court judge is allowed to set aside any rule which conflicts with its dictates. ${ }^{36}$ The model of adjudication sketched out in the Dispatch Court writings is taken by him as representing Bentham's ideal of judicial decision and the role of the judges. In this model, the judge decides with direct reference to utilitarian calculations, which take the form of a balance between existing expectations. It is the judge's task to minimize disutilities and particularly frustration of the suitors' expectations. To do this, he/she will be subject to no fixed rule. Instead, he/she will have to put him/herself in the suitors' shoes and try to assess whether the final decision will cause 'such uneasy sensation as that expressed by the word disappointment'. ${ }^{37}$ When it is the case that two conflicting expectations must be taken into account, the judge will have to form an estimate of their relative strength and to give precedence to the strongest.

Postema's use of the Dispatch Court writings is criticized by Dinwiddy, who denies that these contain the pattern for Bentham's general theory of adjudication. In Dinwiddy's view, Bentham's proposal was meant to work under a common law system and was no model for adjudication under an ideal utilitarian system of statute law. There is no evidence, in his opinion, that absence of general fixed rules of procedure would be recommended by Bentham also for a system based upon his ideal Pannomion. There is a passage in particular in the Equity Dispatch Court Proposal of which Postema and Dinwiddy have given contrasting interpretations. Addressing the victims of the delay, vexation, and expense attached to contemporary judicial procedures, Bentham explains that:

\footnotetext{
${ }^{34}$ Ibid., p. 388; see also Postema, Common Law Tradition, p. 415.

35 'Equity Dispatch Court Bill' in Bowring, iii. p. 312.

36 Postema, Common Law Tradition, p. 418. The importance attached by Bentham to the nondisappointment principle and to the security of expectations in the law has been analysed in Kelly, Utilitarianism and Distributive Justice.

37 'Equity Dispatch Court Bill' in Bowring, iii. p. 388.
} 
[...] for the dispatch of suits, in which it is your misfortune to be embarked, - no regard need to be paid, or ought to be paid, to any rules, on which, in the Courts in which you are respectively undergoing plunderage, the proceedings have been grounded. For, [...] no decision can be more decidedly in contradiction to any one of those rules, than, in instances in vast abundance, those same rules are to one another; and [...] accordingly a much better chance for the prevention of disappointment will be obtained, by aiming at that object immediately, than by aiming at it through so unconducive, and in every respect unapt a medium, as that which is composed of those same rules. ${ }^{38}$

Postema has taken this as proof of a direct-utilitarian approach. The judge should adjudicate according to autonomous utilitarian calculations. The nondisappointment principle can be taken as a deputy of the principle of utility, due to the weight of expectation utilities. The Dispatch Court epitomizes a system of procedure in which the judge is free both from substantive and from procedural constraints. ${ }^{39}$ In Dinwiddy's view, instead, Postema misunderstands the above passage. The rules attacked by Bentham in this context are clearly only those which operated in English Equity Courts. These rules were contradictory and unsatisfactory; they were unable to secure non-disappointment of expectations. Leaving the judge free to weigh and balance the expectation utilities at stake, then, was preferable to tying his/her hands with pointless rules. In Dinwiddy's opinion, anyway, the quoted passage provides no evidence of a general opposition to fixed rules in Bentham's theory of adjudication. ${ }^{40}$

Dinwiddy seems to be right in interpreting the passage as concerning specifically those rules of procedure which were followed in English Equity Courts. Postema, by the way, only quotes the last part ('a much better chance for the prevention of disappointment will be obtained, by aiming at that object immediately, than by aiming at it through so unconducive, and in every respect unapt a medium, as that which is composed of those same rules'). He misses the specific reference to those rules which slowed down and complicated Equity suits, not unlike common law

\footnotetext{
${ }^{38}$ Ibid., p. 312.

${ }^{39}$ Postema, Common Law Tradition, pp. 415-416.

${ }^{40}$ Dinwiddy, 'Adjudication', p. 158.
} 
ones. Such fixed rules, moreover, were unable to secure expectations, because they were obscure and mutually contradictory.

On the other hand, Dinwiddy's suggestion that the Dispatch Court judge is no general model of Bentham's ideal judge cannot be accepted. In several passages, both in the Proposal and in the Bill, the proposed system of procedure is spoken of as the natural system, as opposed to the technical. ${ }^{41}$ It is quite clear that Bentham is referring here to the same natural system of procedure which he had outlined in the Scotch Reform writings, more than twenty years before. Moreover, freedom for the judges from mandatory procedural rules is advocated by Bentham throughout all his works on judicial procedure. In his Principles of Judicial Procedure (written in the 1820s), for instance, he devises a procedural code, but specifies that 'of the several rules laid down in this code, there is not one that is meant to be regarded as inflexible; no one is there, from which, in case of necessity, the judge may not depart' ${ }^{42}$

Bentham's anti-nomianism in procedural matters, then, is not confined to the specific problems of contemporary Equity Courts. Although proposing a different interpretation from Postema, Dinwiddy seems here to confuse substantive and procedural law much like him. It is true that direct evaluation of expectations by the judge, as prescribed by Bentham in the Dispatch Court writings, can be seen as applying exclusively to the particular situation of a natural-procedure court adjudicating in a common law framework. Under Bentham's Pannomion, the judge would have to adjudicate applying the laws enacted by the legislator and contained in the complete code. On the other hand, procedural law in Bentham's view should be free from fixed rules, both under an ideal system of codified law and under the existing system of common law, in which his Equity Dispatch Court would work. In the latter case, substantive law is in effect 'judge-made law' and 'ex-post-facto law'43 and can allow only feeble and uncertain expectations on the part of the citizens. Nonetheless, some expectations do arise and the Dispatch Court judge must respect and safeguard them. This is why he/she has to appeal directly to the non-

\footnotetext{
${ }^{41}$ See for example 'Equity Dispatch Court Bill', and 'Equity Dispatch Proposal', both in Bowring, iii. pp. 331, 306.

42 'Principles of Judicial Procedure' in Bowring, ii. p. 32.

${ }^{43}$ A Comment on the Commentaries and A Fragment of Government, ed. J. H. Burns, H. L. A. Hart, and P. Schofield, Oxford, $2008(C W)$, pp. 49-51n [hereafter Commentary $(C W)$; Of Laws in General, ed. H. L. A. Hart, Oxford, $1970(C W)$, p. 187n [hereafter $O L G(C W)]$. A new edition of the latter text, established by Prof. Philip Schofield, was published in May 2010, entitled Of the Limits of the Penal Branch of Jurisprudence.
} 
disappointment principle (which is in fact a deputy of the principle of utility). As no reliable and stable rules are available for judicial decision to be grounded upon, the judge will be left free to weigh and balance the parties' expectations.

Of course, under the Pannomion things would be very different, because the complete code would provide a stable basis for the citizens' expectations to be built upon: the non-disappointment principle itself, then, would prescribe strict adherence to the code, not direct evaluation of expectation utilities by the judge. Bentham would see this as a matter of substantive law and in this case the Equity Dispatch Court would be no model for courts working in a framework of codified substantive law. On the other hand, the proposed Court displays all the main features of the natural system of procedure, like freedom for the judge to adjudicate with no regard for fixed procedural rules and to minimize delay, vexation, and expense - that is, to appeal directly to the principle of utility. This would be seen by Bentham as a matter of adjective law and, in this case, the Dispatch Court can be taken as a model even for courts adjudicating under an ideal system, based on the Pannomion.

\section{The nature of the Pannomion}

An important part of Postema's overall interpretation concerns the characteristics of Bentham's complete code of laws or Pannomion. In Postema's view, this code would not consist of a very large set of highly specific rules for the judges to apply, which would leave no room for direct appeals to the principle of utility at the level of adjudication. The Pannomion would rather be a set of 'a somewhat smaller number of quite general rules broadly defined ${ }^{44}$. Postema argues that Bentham did not see the completeness of the code as threatened by judicial discretion. Completeness would lie in a rational, all-comprehensive method, which would allow systematic arrangement of laws; it would not consist of the capacity of foreseeing and regulating every possible human action, by means of an enormous amount of very precise rules which would eliminate judicial discretion. On this interpretation,

Bentham's theory [...] allows judges considerable freedom to consult directly the principle of utility when deciding particular cases. This power is available to judges even when the law within which they work

\footnotetext{
${ }^{44}$ Postema, Common Law Tradition, p. 430.
} 
is an ideal, comprehensive, utilitarian code. But this suggests that either the judge is free to ignore the code at will, or that the code is composed of little more than broad general principles which must be applied in particular cases only with the help of the principle of utility. ${ }^{45}$

Postema's 'revisionist' interpretation has the merit of leaving behind the received view of Bentham's judge as the Montesquieuan bouche de la loi, whose application of the law could be seen as a wholly mechanical, non-discretionary process. Bentham's prescriptive theory of judicial interpretation is much more sophisticated than this and allows both for a 'strict' and for a 'liberal' interpretation on the part of the judges. While the former is meant to apply the actual will of the legislator as expressed by the text of the law, the latter goes beyond the text to apply the hypothetical will of the legislator, whenever it looks clear that the letter of the law expresses inadequately what the legislator meant. This is in effect an alteration of the law by the judges, although in a weak sense. ${ }^{46}$ Moreover, Bentham distinguishes between a 'power of imperation de classibus' and a 'power of imperation de singulis'. The first is the power to issue general commands regarding classes of acts and of people, and it belongs to the legislator. The second is the power to issue particular orders concerning individual cases, and it belongs to the judge. The power of imperation de classibus 'even though it be supreme, can never of itself be absolute and unlimited'. ${ }^{47}$ This is so because laws produced by the legislature need to be written in general terms ('generic names'), which establish classes of people, of acts etc.; anyone who, like the judges, has the power to decide whether a certain person or thing or act belongs to the general class, holds thereby a power which limits that of the legislature. ${ }^{48}$ Such a theory makes Bentham a forerunner of Herbert Hart in that he recognizes a fringe of vagueness or 'open texture' pertaining to all rules laid down in general terms. This open texture, which characterizes all rules expressed in natural languages, makes it impossible to wholly predetermine application of the rule to any

\footnotetext{
${ }^{45}$ Ibid., p. 422.

${ }^{46}$ See $O L G(C W)$, pp. 161-164.

${ }^{47}$ Ibid., p. 91.

${ }^{48}$ See $O L G(C W)$, pp. 80 ff. Bentham calls this 'accensitive power', from the latin accenseo ('to aggregate to a class').
} 
particular case, thus leaving a margin of discretion to the interpreter; ${ }^{49}$ in this view, then, adjudication processes can never be entirely mechanical or deductive.

However, Postema's interpretation of the general characteristics of the Pannomion does not find sufficient support in Bentham's writings. Having assumed that Bentham's theory of adjudication is an entirely direct-utilitarian one, Postema puts forward, with regard to the Pannomion, a choice between two alternatives: either 1) the laws contained in the complete code can be set aside by the judge whenever he/she thinks it necessary, or 2) the code does not contain mandatory laws, but rather broad principles for the judge to apply discretionally at case-level, with the help of direct utility calculations.

The first of the proposed alternatives seems to suggest that the laws contained in the code should not be seen as mandatory rules, but rather as advice from the legislator to the judges. This clearly conflicts with all those passages in which Bentham explains that laws can be seen as commands issued by the legislature, with the exception of those expressing a countermand. There are only three reasons why the word 'command' cannot be used as a perfect synonym of 'law':

1. It gives no intimation that the will in question is in any manner referable to sovereign. 2. It does not include a countermand, and 3. It is not applicable without some degree of harshness to any material instrument, such as a written or printed paper whereby the will in question is expressed. When applied to anything written, it seems to denote the will which is expressed, in exclusion of the writing by which it is expressed. ${ }^{50}$

Bentham here does not even hint at the fact that a law could also constitute a simple piece of advice, with no imperative character. Sometimes he uses 'law' and 'command' as synonyms. ${ }^{51}$ The reason is that laws have as their central and indispensable part an 'imperative provision': the imperative provision is the basic unit which could even constitute a complete law by itself. ${ }^{52}$ The laws contained in the Pannomion, then, cannot be seen as so many pieces of advice to the judge. It is true

\footnotetext{
${ }^{49}$ See H. L. A. Hart, The Concept of Law, $2^{\text {nd }}$ ed., Oxford, 1998, pp. 123, 127-128.

${ }^{50} O L G(C W)$, p. 10.

${ }^{51}$ See for example IPML $(C W)$, p. 308: '[...] one and the same law, one and the same command'.

${ }^{52} O L G(C W)$, pp. $115,124$.
} 
that Bentham recognizes that a legal system also incorporates laws which are neither commands nor prohibitions, namely permissive laws. ${ }^{53}$ These are not imperative and could possibly constitute an instrument used by the legislator to communicate with judges and citizens in general: they might be seen as a way of pointing out to them what the laws do not prohibit (nor command). If there is room in Bentham's theory for laws which can be seen as simply advising a certain behaviour, not commanding nor prohibiting it, this must be looked for in the field of permissions. But permissive laws have a secondary or parasitic role in Bentham's system and can only be seen as confirming legal liberties, in the sense that they work in an imperative framework and mark out those spaces of 'natural liberty' which have been left untouched by legal restrictions. In his opinion, the laws in a legal system work mainly in an imperative fashion. ${ }^{54}$ This sometimes leads him to oversimplify his own views and to state, probably with polemical purposes, that all laws have an imperative character. ${ }^{55}$ To be sure, the great majority of laws in Bentham's view can be seen as commands or prohibitions, that is as mandatory rules, not as simple recommendations. This does not mean that no room for mere advice is to be found in the Pannomion; as we have already seen, a procedure code is conceived by Bentham as a set of recommendations and rules of thumb. But (the great majority of) the laws to be contained in the complete code are mandatory and cannot be set aside by the judges, as if they were so many pieces of advice.

The second alternative proposed by Postema is that the Pannomion would not contain precise rules, but rather broad principles that would leave great liberty to the judges. These principles would be simple guidelines for adjudication. The judges would have great freedom in interpreting and applying them at case-level, with the help of direct appeal to the principle of utility. Postema here seems to conceive of principles as very broad rules, with a very low degree of specificity. Principles, then, should guide action in the sense that they inspire it, not that they command it. Moreover, as we have already seen, Postema suggests that the intrinsic indefiniteness of these rules would mean that the code should contain a relatively small number of

\footnotetext{
${ }^{53}$ Ibid., p. 15n; also IPML (CW), p. 299.

${ }^{54}$ See D. Lyons, 'Logic and Coercion in Bentham's Theory of Law', Cornell Law Review, vol 57 (1972), pp. 335-362. This piece was reprinted in Jeremy Bentham: Critical Assessments, ed. B. Parekh, 4 vols., London, 1993, ii.

${ }^{55}$ See $O L G(C W)$, p. 54; also Lyons, 'Logic and Coercion'.
} 
them if compared with a code made of very precise and specific rules. This interpretation poses several problems.

Firstly, it is not clear what degree of specificity the rules contained in the Pannomion should have in Bentham's view. It may well be that he conceived of them as broad and generic directives, but Postema does not show conclusive textual evidence of this. It seems that he bases this hypothesis only upon his interpretation of the role of the judges under the Pannomion; an interpretation which, as we have seen, seems to misplace direct-utilitarian decisions by extending them from the field of procedures to that of substantive law.

Secondly, Postema argues that the Pannomion should contain a relatively small number of rules - which would also involve a low degree of specificity. Once again, we have no clear evidence of this. It is true that, as Postema explains, Bentham saw simplicity as an indispensable requisite of his ideal code, because it would have enabled every citizen to consult it without the help of a professional interpreter, that is of a lawyer. Postema quotes the following passage from Principles of the Civil Code:

Every man has his determinate measure of understanding: the more complex the law, the greater the number of those who cannot understand it. Hence it will be less known; it will have less hold upon men; it will not occur to their minds on the occasions on which it ought, or, what is still worse, it will deceive them, and give birth to false expectations. Both style and arrangement ought to be simple. The law should be a manual of instruction for every individual, and he ought to be able to consult it, under all doubts, without requiring an interpreter. ${ }^{56}$

However, this passage does not seem to support the claim that the Pannomion should contain only a small number of laws. Bentham is speaking here of the form of the code, which should favour its cognoscibility; in the same page he goes on to explain that

the more conformable laws are to the principle of utility, the more simple will be their systematic arrangement. A system founded upon a

\footnotetext{
56 'Principles of the Civil Code' in Bowring, i. p. 324.
} 
single principle may be as simple in its form as in its foundation. It is only susceptible of a natural arrangement and of a familiar nomenclature. ${ }^{57}$

No reference is here made to the number of laws contained in the code. A 'natural arrangement' and a 'familiar nomenclature' could characterize both a very ample and a very small set of laws. Bentham seems here to relate simplicity with a rational structure and a plain, common, and easily understandable language. This rational structure is one based upon the classification of the different offences, 'fictitious entities' which can be classified according to the different genera and species of harm that the legislator wishes to prevent. Such a 'natural arrangement' as opposed to the 'technical arrangement' - is 'the order according to which the law would be most easily consulted' ${ }^{58}$ Bentham recognizes that the masses do not have the time and the capacity to inquire into a body of laws featuring abstruse classifications and employing technical, uncommon terms. The method of arrangement, then, should be intuitive and the words in the code should belong as far as possible to everyday language. ${ }^{59}$ This is the simplicity looked for by Bentham and it does not necessarily involve keeping down the number of laws. Moreover, he did not hold that the complete code should be known in depth by all citizens and in all his parts. The Pannomion should rather be an easy-to-consult instrument, in which everyone could be able to find the law or laws applying to his/her case. Careful promulgation would allow the legislator 'to impose upon each man the task of being acquainted [with] just a number of [laws] as concerns himself and no more' ${ }^{60}$ In this way, Bentham sought to reconcile the desirable 'brevity' in exposition of the laws with the 'amplitude in point of matter' that was requisite. ${ }^{61}$ There was no need, then, for the complete code to contain a small number of laws in order to allow the citizens to learn them: a huge set of rules could attain the same results with a 'natural arrangement'. In Nomography, Bentham considers 'overbulkiness' as a possible defect of a body of laws but explains that the absolute dimensions of the code do not really matter, as long as its accessibility to the citizens is guaranteed:

\footnotetext{
${ }^{57}$ Ibid.

58 'A General View of a Complete Code of Laws' in Bowring, iii. p. 161.

${ }^{59}$ Ibid., pp. $161 \mathrm{ff}$.

${ }^{60}$ UC lxxix 30, in D. Lieberman, 'Bentham's Digest', The Bentham Newsletter, vol 9 (1985), p. 12.

${ }^{61}$ Ibid.
} 
So as each individual have but the advantage and comfort of beholding effectually within his reach — within the reach of his purse, as well as of the mastery of his mind, whatsoever parts he is in any way concerned in point of interest to be acquainted with, the bulk of the whole, how vast soever, is with reference to him a matter of indifference: overbulkiness is not with relation to him among the properties that belong to it. ${ }^{62}$

The Scotch Reform manuscripts contain a passage which could be seen as supporting Postema's interpretation:

Taken by itself, every law [...] is prima facie an evil: its very existence is prima facie evidence of its mischievousness. Even supposing no fresh load of obligation imposed by it, still the new law is prima facie an evil: for if not on the will, it is at any rate an additional load on the understanding: it adds to the difficulty of comprehending and thence of being governed by, the rule of action taken in its whole extent: it adds to the uncognoscibility, to the relative uncertainty, of the whole body of the laws. ${ }^{63}$

Bentham, then, is against the hypertrophy of law and in favour of reduction to a minimum of the number of rules in the code. But what does this minimum amount to? Should the code contain hundreds or hundreds of thousands of laws? Once again, here we have no textual evidence that the Pannomion should contain a relatively small number of broad principles instead of a larger number of precise laws. It could very well be that the smallest necessary number of rules is indeed a very large one.

Lastly, not only does Postema hold that the rules in the code should be broad and generic and that they should be relatively few, but he adds that they should be applied by the Benthamic judge "with the help of the principle of utility' ${ }^{64}$ How should this be interpreted? If this means that substantive law should be applied with procedures which include direct-utilitarian calculations, then Postema is right, as we have already seen. But if Postema relates this to the two other alleged characteristics of the code - namely, that

\footnotetext{
62 'Nomography' in Bowring, iii. p. 239. See also The Common Law and English Jurisprudence 17601850, M. Lobban, Oxford, 1991, p. 125n.

${ }^{63}$ UC xciv 201.

${ }^{64}$ Postema, Common Law Tradition, p. 422.
} 
its rules should be few and very generic - meaning that even under the Pannomion judges should decide substantive matters applying directly the principle of utility, then he has no sufficient textual support for his view, as we have already seen.

\section{Conclusion}

Postema's view of Bentham's theory of adjudication as a direct-utilitarian one needs to be amended in several respects. It is true that Bentham advocates freedom for the judges to pursue directly the maximization of utility in procedural matters, but this does not bear reference to application of substantive law and does not make them free to dispense with it. In Bentham's view, judges do have to make direct-utilitarian calculations, but these are mainly confined to the field of 'adjective law' and, most of all, to admission of evidence. Whenever they reckon that the substantive law as it is would obtain anti-utilitarian results, they are under the obligation of staying its execution and of referring this to the legislature. This latter shall decide whether to amend the law in accordance with the judge's suggestion. If this happens, the judge will apply the modified law to the case which called for the amendment. This is how the legal system will receive its necessary flexibility. In Bentham's view, judges should by no means be allowed to set aside the law and decide applying directly the principle of utility.

The Equity Dispatch Court writings offer a model of Benthamic adjudication under a system of non-codified law. Postema is right in pointing out that Bentham's utilitarian judge must be conferred considerable powers in deciding according to direct-utilitarian calculations; but, once again, these powers only concern the field of procedure, not that of substantive law. It is true that in the Equity Dispatch Court writings Bentham suggests the judges should adjudicate pursuing directly the minimization of the disappointment of the parties. It is also true that this in fact amounts to deciding by applying the principle of utility, which in this case takes the form of the 'non-disappointment principle'. But prevention of disappointment and security of expectations require different tasks of the judges under a common law system than under a completely codified body of laws. Under Bentham's ideal Pannomion, the citizens' expectations would focus on the code and the nondisappointment principle would prescribe the application of the rules contained in it. While the Equity Dispatch Court offers a model of ideal utilitarian procedures, it is 
meant to work under a non-ideal system in which substantive law is not codified, and thus cannot be seen as exemplifying adjudication under the Pannomion.

Lastly, Postema's account of the characteristics of the complete code of laws or Pannomion, which would allow the judges to adjudicate free from legislative constraints and apply directly the principle of utility, does not seem to receive sufficient textual support. The view that the rules in the code should not be binding on the judges clashes with Bentham's conception of the laws as mandatory rules (with the exception of permissive laws). The alternative view that the rules in the code should be relatively few and very broad and generic does not find textual evidence. Bentham explicitly conceives of procedural rules as non-mandatory generic principles or pieces of advice; but this does not apply to substantive laws.

Copyright $@$ (2010, Francesco Ferraro. This file may be copied on the condition that the entire contents, including the header and this copyright notice, remain intact. 